\title{
EVALUATION THE ROLE OF SALES PROMOTION IN INFLUENCING IMPULSE BUYING BEHAVIOR: A COMPARISON BETWEEN INTERNATIONAL AND LOCAL TOURIST AT PREMIUM OUTLET IN MALAYSIA
}

\author{
Sharifah Faridah Syed Ali ${ }^{1}$ \\ Faculty of Economics and Management, \\ Universiti Putra Malaysia, Malaysia \\ (Email: sha_faridah@yahoo.com) \\ Yuhanis Abdul Aziz ${ }^{2}$ \\ Faculty of Economics and Management, \\ Universiti Putra Malaysia, Malaysia \\ (Email: yuhanis@upm.edu.my) \\ Raja Nerina Raja Yusuf ${ }^{3}$ \\ Faculty of Economics and Management, \\ Universiti Putra Malaysia, Malaysia \\ (Email: nerina @upm.edu.my) \\ Ng Siew Imm $^{4}$ \\ Faculty of Economics and Management, \\ Universiti Putra Malaysia, Malaysia \\ (Email: imm_ns@upm.edu.my)
}

Accepted date: 23-03-2019

Published date: 30-06-2019

To cite this document: Ali, S. F. S., Aziz, Y. A., Yusuf, R. N. R., \& Ng, S. I. (2019). Evaluatioan The Role of Sales Promotion in Influencing Impulse Buying Behavior: A Comparison Between International Local Tourist at Premium Outlet in Malaysia . Journal of Tourism, Hospitality and Environment Management, 4(15), 32-43.

DOI: $10.35631 /$ JTHEM.415004

\begin{abstract}
The growing number of premium outlets in Malaysia has led to a new shopping experience to both local and international tourists. Associated with the concept of 'everyday discount', premium outlets would attract more consumers to purchase at the outlets. Previous studies have revealed the significant influence of sales promotion on consumer purchase behaviour as well as impulse buying behaviour. However, there are limited studies identifying the role of sales promotion on impulse buying behaviour in the perspective of international and local tourists. Moreover, previous research of literature on the premium outlets, especially in Malaysia are still lacking. Therefore this study aims to evaluate the role of sales promotion on impulse buying in the perspective of international and local tourists at premium outlets in Malaysia. Data were collected from 359 tourists at five premium outlets in Malaysia, using a self-administered questionnaire. The result of the study indicates that both groups have different preferences in terms of sales promotion that induced them to make an impulse purchase. This study suggests that retailers or marketers should improvise their pricing strategies and give out more samples and gifts to attract tourists to spend more money.
\end{abstract}


Keywords: Sales Promotion, Impulse Buying Behaviour, Premium Outlet, Local And International Tourist

\section{Introduction}

Tourism industry has rapidly been growing for the last two decades and now has been recognised as one of the largest and fastest growing sectors (Habibi, 2016). According to UNWTO (2018), the tourism industry brings about billions of income, where it generates USD 1.6 trillion in export, $10 \%$ of words GDP, $7 \%$ of world's export, $30 \%$ of services export and1/10 job opportunities. In fact it is ranked as third in worldwide export category after chemical and fuel. The number of people travelling increases gradually, where in Europe the arrival increased 3.3\% every year from year 2005 until 2017. In Asia Pacific, South East Asia has great demand of destination where the total average is approximately $7.8 \%$ (UNWTO, 2018).

Malaysia is one of the South East Asia countries that receive a billion number of tourist arrival. Tourism industry in Malaysia contributed RM167.5 billion to gross domestic product (GDP) in year 2016 (WTTC, 2017). One of the biggest tourism sectors that contribute to the nation economic is shopping tourism. It contributed $31.7 \%$ of total tourism revenue in 2016 and RM26.03 billion of tourist expenditure was spent on shopping (Tourism Malaysia, 2017). Corresponding with this, the government has developed a strategic plan known as National Key Economic Area (NKEA) for tourism development. In this plan, the government has outlined 12 Entry Point Projects (EPP), whereby three of the projects involve shopping tourism that falls under "luxury affordable" theme (Tourism Malaysia, 2015). The aim of this project is to increase tourism revenue, where one of the strategies is by developing the premium outlets.

There are currently five premium outlets in Malaysia, namely Johor Premium Outlet (JPO), Mitsui Outlet Park (MOP), Freeport A'Famosa Outlet, Design Village Outlet (DVO) and Genting Premium Outlet (GPO). The development of premium outlets in Malaysia is rather new as compared to the United States (US) where there are currently more than 200 outlet malls with 15,000 stores (Sierra and Hyman, 2011). The outlet malls in the United States are now very competitive compared to traditional malls, where they changed consumers' shopping behaviour (Reynolds, Ganesh and Luckett, 2002). Recognising the potential of outlet malls, the government targets to earn RM900 million from three of the outlets by year 2020 and uses tourism as a key driver to increase tourist expenditure on shopping. The new concept of shopping environment that offers attractive discount every day with unique architecture would bring exciting shopping experience to local and international tourists in Malaysia.

Since the development of the outlets increases the revenue in shopping tourism, there are several ways to induce tourists to spend more. Previous scholars have indicated that impulse buying is one of the ways that could increase retail profit as well as tourism revenue (Foroughi, Buang, and Sherilou, 2011; Laesser and Dolnicar, 2012; Li, Deng, and Moutinho, 2014). According to Cheng et al (2013) impulse buying contributes $62 \%$ of supermarket sales and $80 \%$ of sales in several product categories. Meanwhile, Abrahams (1997) stated that impulse buying could contribute USD4 billion of total annual revenue. When the retailers effectively attract consumers to purchase instantly, they would increase the revenue. 
Therefore, retailers would experience the benefits of impulse buying and thus contribute to tourism revenue. Several scholars have studied impulse buying behaviour in the context of consumer behaviour as well as tourism (Li, Deng, and Moutinho 2014; Akram et al, 2018; Husnain et al, 2019). These studies have found several factors that influence impulse buying behaviour and one of the factors is sales and promotion. Past literatures stated that sales promotion is one of the mechanisms that induce consumer towards making a purchase on impulse (Kchaou and Amara, 2014; Nagadeepa, Selvi, and Pushpa, 2015; Tendai and Crispen, 2009). It is one of the strategies that retailers communicate with the consumers, which is by providing information to consumer as well as persuading and encouraging them to take actions (Moharana and Pattanaik, 2016; Tariq Kahn, 2014). Since the outlets are offering the discounts every day, the possibility to having an induced consumer to purchase on impulse is relatively high. However, there are no empirical studies that discuss on the effectiveness of sales promotion offered at the outlet malls.

On the other hand, there are very limited literature that gave an attention to the outlet malls. According to Karande and Ganesh (2000), even though the growth of outlet malls significantly contributes revenue to the market industry, there is limited study on outlet malls. In fact, past literatures are more focused on the consumer profile (Kirande and Ganesh, 2000) or shopper typologies (Reynolds, Ganesh and Luckett, 2002) in the outlet malls despite having the concept of "discount every day". Therefore, to fulfil this gap this study will analyse the effectiveness of sales promotion in influencing tourists' impulse buying at the outlet malls. Researchers have long identified shopping behaviour among tourists and the implication for retail managers. However, limited study was found to focus on the impact of sales promotion on local and international tourists in influencing their impulse buying behaviour. Therefore, this study attempts to evaluate the role of sales promotion in impulse buying from the perspective of international and local tourists. This study would be helpful for the retailers to understand the effectiveness of sales promotion from the perspective of international and local tourists that would influence them to purchase on impulse. Understanding both international and local tourists is critical to segment the market as well as to formulate the strategies and tactics to increase tourists' shopping spending. Hence, this research objective is to evaluate the role of sales promotion in influencing international and local tourists' impulse buying behaviour at premium outlets in Malaysia.

\section{Literature Review}

\section{Sales Promotion}

Sales promotion is one of the ways for marketers to persuade and remind potential consumers of their product in order to influence them to make a purchase (Lamb and McDaniel, 2010 cited in Andreti et al, 2013). It can be defined as marketing communication activities (Alvarez and Casielles, 2005; Peattie, 1998) or incentive used by marketers and manufacturers to persuade consumers to make a purchase (Shimp, 2003). Kotler (2005) stated that sales promotion is the main component in marketing to stimulate consumers to make a greater purchase of particular product of services. It normally occurs in a long-term or shortterm period that offers above normal offerings to achieve marketing objectives (Brassington and Pettitt, 2000).

Past literature have studied sales promotion in order to analyse consumer buying behaviour such as impulse buying behaviour (Metilda and Kartika, 2015; Liao, Shen, and Chu, 2009; $\mathrm{Xu}$ and Huang 2014), intention to purchase (Weng and Run, 2013; Chaharsoughi and Hamrad, 2011; Ye and Zhang 2014; Santini et al, 2015), and consumer purchase decision 
(Panda 2016; Kiran et al, 2012; Andreti et al, 2013). According to Andreti et al (2013) sales promotion plays an important role that influences consumer purchase decision. The authors suggested that by doing more attractive promotions, offering more discounts and serving customers well, marketers can encourage more consumer participation and increase customer purchase intention. On the other hand, past scholars found that sales promotion is the best mechanism to attract consumers to purchase on impulse (Lee and Tsai, 2014; Shuleska, 2012; Lo, Lin, and Hsu, 2015). Metilda and Kartika (2015) have studied the impact of sales promotion on hedonic value and utilitarian value on impulse buying behaviour. The study has found that sales promotion has a strong connection with hedonic and utilitarian shoppers to purchase on impulse. However, Chaharsoughi and Hamrad (2011) indicated that sales promotion does not have a strong relationship with impulse buying. The authors signified that not all consumers will be attracted with the promotion and every consumer has his/her own preferences prior to making a purchase.

Buil, Chernatony, and Martinez (2013) conducted a study on the relationship of sales promotion, brand equity and perceived quality. The finding showed that sales promotion has a negative relationship with perceived quality but not on brand equity. Contrarily, ValetteFlorence, Guizani, and Merunka (2011) have found that sales promotion has a negative connection with brand equity. The authors indicated that frequent sales promotion gives a negative impact on brand value. This means that the occurrence of mixed result is due to the research that has been conducted on different situations with different respondents. Overall, past scholars have emphasised the benefits and weaknesses of sales promotion. The mixed results of sales promotion towards consumer purchase buying show that there is a need in future research to further examine the role of sales promotion on consumer purchase behaviour.

\section{Impulse Buying Behaviour}

Impulse buying behaviour is defined as a spontaneous purchase where consumer buys something without planning in advance (Kollat and Willet, 1969; Stern, 1962). It is the situation where the consumer just takes a product that attracts his/her attention rather than considering and this purchase happens fast and urgently (Saad and Matawie, 2015). Meanwhile, Hadjali et al (2012) indicated that spontaneous purchase happens when an individual does not look for a specific product or brand name and has no intention to make a purchase. In contrast, Berman and Ivan (2004) classified that the occurrence of impulse buying is not only due to no planning in advance. However, it would take place when the consumer has decided in advance, classified the situation as partially unplanned and unplanned situation. Partially unplanned is a situation where the consumer has planned to make a purchase without any specific brands or models. On the other hand, an unplanned situation refers to when a consumer has planned to purchase a specific brand or model but changes it once he or she comes into contact with retailer. Therefore, impulse buying behaviour could also happen when the consumer have planned in advance as well.

The literature of impulse buying has been studied for over 60 years. It has been covered in several fields of study including tourism. In tourism, impulse buying is defined as a planned purchase where tourists have considered taking a vacation before booking (Laessar and Dolnicar, 2012). The authors signified that planning for a trip to one particular destination including the choice of transportation, income, information sources can lead tourists to making an impulse purchase. Therefore, Stern (1962) has stated that pure impulse buying does not occur in tourism but it might occur in the context of tourism perspective. In the perspective of shopping, Babin, Chebat, and Michon (2014) stated that tourists might not 
have the intention to shop before travelling may fall into shopping in order to experience another culture. Therefore, tourists may lead themselves into shopping if there is a good bargain with attractive promotion. Past literature Li, Deng, and Moutinho (2014) has found that experiencing activities is one of the factors that induce tourists to make a purchase on impulse. Generally, tourism is broad, therefore the studies of impulse buying behaviour in the perspective of tourism might produce mixed results accordingly to tourism products.

In the context of consumer behaviour, past literatures have studied the factors that influence consumers to make an impulse purchase (Virvilaite and Saladiene, 2012; Floh and Madlbeger, 2013; Raju, Kumar, and Raju, 2015). Radzi, Hamid, and Yasin (2017) have studied impulse buying behaviour in the context of the Malaysian airport. The finding of the study shows that store environment significantly positive with impulse buying behaviour. Meanwhile, Sharma and Nanda (2012) who studied the impulse buying tendency in the similar context found that impulse buying tendency does not influence consumers to make a purchase on impulse. This is in contrast with Badgaiyan, Verma, and Dixit (2016) study, where there is positive relationship with impulse buying tendency with impulse buying behaviour. Therefore, the connection of impulse buying tendency with impulse buying behaviour occurs accordingly to different situations is associated with several factors. Instead of store environment, emotion is another factor that drives consumers to purchase on impulse (Verplanken and Herabadi, 2001; Lucas and Koff, 2014; Sohn and Lee, 2016; Rook, 1987). Consumers make an impulse purchase when they feel sad, angry or stressed (Rook and Gardner, 1993). Meanwhile Sohn and Lee (2016) signified that positive emotion leads consumer to make an impulse buying. Prior researchers also indicated that demographic factors would lead to impulse buying behaviour (Karbasivar and Yarahmadi, 2011; Xu, 2007; Amos, Holmes, and Keneson, 2014). However, Amos, Holmes, and Keneson (2014) affirmed that demographic factors produce mixed results. The author indicated that young generation highly tend to make an impulse buying as compared to X generation. Nevertheless, young generation are inclined to purchasing on impulse.

Although there have been numerous studies of impulse buying behaviour, the literature is still limited. There are still mixed results of certain factors that contribute to impulse buying behaviour. Moreover, there are still limited studies to understand the impulse buying behaviour in the perspective of international and local tourists. Therefore there is still a need for more literatures in impulse buying behaviour.

\section{Methodology}

Subjects of this study included two groups, which were international and local tourists who made a purchase at premium outlet sin Malaysia. A purposive, non-probability sampling was employed due to unavailability of list of international and local tourists shopping at the premium outlets. The self-administered questionnaires were distributed to 359 respondents which only shopped at premium outlets in Malaysia, namely Johor Premium Outlet (JPO), Mitsui Outlet Park (MOP), Freeport A'Famosa Outlet, Genting Premium Outlet (GPO) and Design Village Outlet (DVO). The questionnaire regarding sales promotion was obtained from Lo and Qu (2015), Wakefield and Barnes (1996) and Park et al (2012). It was measured via a 7-point Likert scale from strongly disagree (1) and strongly agree (7). SPSS 23.0 was used to analyse the data. The t-test analysis was employed in order to compare both groups. Meanwhile, ordinary least squares (OLS) multiple regression analysis was employed in order to analyse the influence of sales promotion on impulse buying behaviour for international and local tourists. The demographic characteristics of respondents are presented in Table 1 and deliberately explained in the next section. 


\section{Result and Discussion}

\section{Profile of The Respondent}

Profile of the respondents is presented in Table 1. The result shows that majority of the respondents are female (57.4\%) aged between 25 to 35 . The total of 359 respondents consists of local tourists (72.1) and international tourists (27.9\%). Most of the respondents are married (58.8\%) followed by single (39\%) and divorcee (1.9\%). The highest income of international respondents is between USD1000 to USD2000 and USD2000 to USD3000, where the percentage is $7.5 \%$ each. Meanwhile the highest income for local tourists is between RM2000 to RM3000. The respondents are primarily from private sector $(43.5 \%)$ and government sector $(31.5 \%)$ with majority of them are holders of bachelor degree $(41.5 \%)$ followed by diploma (24.5\%), master degree (19.2\%), high school (11.1\%) and doctorate degree $(3.1 \%)$.

Table 1: Profile of Respondent

\begin{tabular}{|c|c|c|}
\hline $\begin{array}{c}\text { Demographic } \\
\text { information }\end{array}$ & $\begin{array}{c}\text { Frequency } \\
(n=359)\end{array}$ & Percentage (\%) \\
\hline \multicolumn{3}{|l|}{ Gender } \\
\hline Male & 153 & 42.6 \\
\hline Female & 206 & 57.4 \\
\hline \multicolumn{3}{|l|}{ Age } \\
\hline $18-24$ & 65 & 18.1 \\
\hline $25-35$ & 167 & 46.5 \\
\hline $36-44$ & 84 & 23.4 \\
\hline $45-55$ & 35 & 9.7 \\
\hline $56-60$ & 5 & 1.4 \\
\hline Above 60 & 3 & 0.8 \\
\hline \multicolumn{3}{|l|}{ Marital Status } \\
\hline Single & 140 & 39.0 \\
\hline Married & 211 & 58.8 \\
\hline Divorce & 7 & 1.9 \\
\hline Others & 1 & 0.3 \\
\hline \multicolumn{3}{|l|}{ Income (USD) } \\
\hline Below USD 1000 & 25 & 7.0 \\
\hline USD1000 - USD2000 & 27 & 7.5 \\
\hline USD2000 - USD3000 & 27 & 7.5 \\
\hline USD3000 - USD4000 & 15 & 4.2 \\
\hline USD4000 - USD5000 & 2 & 0.6 \\
\hline More than USD5000 & 1 & 0.3 \\
\hline \multicolumn{3}{|l|}{ Income (RM) } \\
\hline Below RM1000 & 20 & 5.6 \\
\hline RM1000-RM2000 & 32 & 8.9 \\
\hline RM2000-RM3000 & 87 & 24.2 \\
\hline RM3000-RM4000 & 42 & 11.7 \\
\hline RM4000-RM5000 & 32 & 8.9 \\
\hline More than RM5000 & 48 & 13.4 \\
\hline
\end{tabular}




\section{Occupation}

\begin{tabular}{lcc} 
Government Sector & 113 & 31.5 \\
Private Sector & 156 & 43.5 \\
Self-Employment & 57 & 15.9 \\
Others & 33 & 9.2 \\
& & \\
Country of Origin & 259 & 72.1 \\
Local tourist & 100 & 27.9 \\
International tourist & & \\
& 40 & \\
Education Level & 88 & 11.1 \\
High school & 149 & 24.5 \\
Diploma & 69 & 41.5 \\
Bachelor degree & 11 & 19.2 \\
Master degree & 2 & 3.1 \\
Doctorate degree & & 0.6 \\
Others & & \\
\hline
\end{tabular}

\section{T-Test Result of Significant Difference of Sales Promotion on Impulse Buying Behaviour}

Table 2 shows the rating of international and local tourists on sales promotion along with the comparison. Overall, most of the ratings on sales promotion were above 5 on the 7-point scale. In general, there were different patterns of both international and local tourists, where "the outlet has attractive discount" item was the highest rated item for international tourists. Meanwhile, "promotion plays a big part in my choice in making a purchase" item obtained the highest rating for local tourists. The second highest rated item for international tourist was that promotion influences their spending and promotion plays big part on their choice of purchase. On the other hand, the availability of special price was the second highest rated item for local tourists. However, a similar pattern existed within both groups, with "the outlet gives out gifts and samples" was the lowest rated item. The result shows statistically significant differences in the t-test for two items, which were 1) outlet gives out gifts and samples and 2) the availability of special prices of the product in the outlet. Generally, this result shows that both international and local tourists have different preferences in terms of sales promotion before making a purchase.

Table 2. Comparison of International and Local Tourist on Sales Promotion

\begin{tabular}{|c|c|c|c|c|c|c|}
\hline $\begin{array}{l}\text { Sales promotion items } \\
\text { (1=strongly disagree and } 7= \\
\text { strongly agree) }\end{array}$ & $\begin{array}{l}\text { Int. } \\
\text { tourist } \\
(\mathbf{n = 1 0 0})\end{array}$ & $\begin{array}{l}\text { Local } \\
\text { Tourist } \\
(\mathbf{n}=259)\end{array}$ & $\mathbf{t}$ & df & $\begin{array}{l}\text { t-Test sig } \\
\text { (2-tailed) }\end{array}$ & $\begin{array}{l}\text { Effect } \\
\text { size } \\
\eta^{2} \\
\end{array}$ \\
\hline & Mean & Mean & & & & \\
\hline $\begin{array}{l}\text { The outlet has attractive } \\
\text { discounts }\end{array}$ & 5.30 & 5.06 & -.463 & 102.93 & .645 & 0.000 \\
\hline $\begin{array}{l}\text { The outlet gives out gifts and } \\
\text { samples }\end{array}$ & 4.58 & 4.17 & -2.33 & 357 & $.020 * *$ & 0.014 \\
\hline $\begin{array}{l}\text { Special prices of the product } \\
\text { are available }\end{array}$ & 4.90 & 5.20 & 2.144 & 357 & $.033 * *$ & 0.012 \\
\hline $\begin{array}{l}\text { Promotion } \\
\text { influences when I visit the }\end{array}$ & 5.00 & 5.07 & .599 & 357 & .550 & 0.001 \\
\hline
\end{tabular}


outlet

\begin{tabular}{|c|c|c|c|c|c|c|}
\hline $\begin{array}{l}\text { Promotion information } \\
\text { influences how much I spend } \\
\text { when I visit the outlet }\end{array}$ & 5.16 & 5.10 & -.376 & 357 & .707 & 0.000 \\
\hline $\begin{array}{l}\text { If there's a promotion I like, I } \\
\text { just go to that particular outlet } \\
\text { instead of another one }\end{array}$ & 4.80 & 4.92 & .760 & 357 & .448 & 0.001 \\
\hline $\begin{array}{l}\text { Promotion play a big part in } \\
\text { my choice to make a purchase }\end{array}$ & 5.16 & 5.38 & 1.514 & 357 & .131 & 0.006 \\
\hline $\begin{array}{l}\text { The price of products in the } \\
\text { outlet is economical }\end{array}$ & 5.01 & 4.94 & -.490 & 357 & .624 & 0.006 \\
\hline
\end{tabular}

*Int. tourist = International tourist

*Significantly $(\mathrm{p}<0.05)$ higher on average

\section{Regression Result on The Influence of Sales Promotion on Impulse Buying Behaviour}

The OLS multiple regression analysis was performed in this study, where impulse buying was used as a dependent variable and sales promotion as independent variable. As shown in Table 3, sales promotion is influential in influencing local tourists to make an impulse purchase. Meanwhile sales promotion is not significant in leading international tourists towards making a purchase on impulse. Therefore, overall sales promotion in the outlet malls ineffectively affects international tourists to make an impulse purchase. Hence, sales promotion in the outlets effectively influences local tourists to make a purchase on impulse.

Table 3. Result of Regression Analysis on The Influences of Sales Promotion on Impulse Buying Behaviour of Local and International Tourist

\begin{tabular}{|c|c|c|c|c|c|c|}
\hline \multirow[b]{2}{*}{ Groups } & \multirow{2}{*}{$\begin{array}{l}\text { Model Fit } \\
\text { Dependent Variable: } \\
\text { Impulse buying }\end{array}$} & \multicolumn{5}{|c|}{ Adj. $\mathrm{R}^{2}=.031 f=9.382 \alpha=0.000$} \\
\hline & & b & S.E & $\beta$ & $\mathbf{t}$ & $\alpha$ \\
\hline \multirow[t]{3}{*}{ Local tourist } & Constant & 13.806 & 2.111 & & 6.539 & .000 \\
\hline & Sales promotion & .160 & .052 & .188 & 3.063 & $.002 * *$ \\
\hline & Model Fit & \multicolumn{5}{|c|}{ Adj. $\mathbf{R}^{2}=.008 \quad f=1.803 \alpha=0.000$} \\
\hline Int. tourist & Constant & 18.854 & 2.430 & & 7.759 & .000 \\
\hline & Sales promotion & .080 & .059 & .134 & 1.343 & .182 \\
\hline
\end{tabular}

$*$ Int. tourist $=$ International tourist

$* * \mathrm{p}<0.005=$ significant level

\section{Implications, Limitation and Conclusion}

The objective of this study is to evaluate the role of sales promotion in influencing international and local tourists' impulse buying behaviour at premium outlets in Malaysia. The findings of this study offer interesting implication for both practitioners and researchers. The outcome shows that even though both groups agree that the outlets provided attractive discount, somehow both international and local tourists rated low on gifted items and samples. Therefore, the retailers or marketers should improvise by giving out more gifts and samples to attract the tourists to make more purchases. As stated earlier, sales promotion at the outlets ineffectively influences international tourists to make an impulse purchase. Therefore, the retailers and marketers should understand more on international preferences 
and shopping behaviour to improvise the price strategies in terms of promotion in order to attract not only international but local tourists to make an impulse purchase. Moreover, the retailers and marketers could improvise the price segmentation in order to attract both groups to make them purchase on impulse.

This research provides insights on how international and local tourists react to sales promotion at the outlet malls. The result suggests that both international and local tourists have different perspectives and behaviour before they make a purchase. Local tourists are more interested in sales promotion that leads them to purchase impulsively. This is similar to Jee and Ernest (2013), where the sales promotion technique may have a significant effect on Malaysia's consumer purchase intention. The findings of the study suggest that the impact of sales and promotional differences between international and local tourists on impulse buying depends on the promotion context. If the promotion is strong, impulse buying may be rated similarly by different tourist segment.

This study presents limitation and has identified avenues for future research. First, the survey was conducted at the duration of specific period which might not cover the overall number of international tourists from different countries. Therefore, future research may conduct a survey at different periods of time in order to get more feedback from tourists from different countries. On the other hand, more studies are required to explore these differences at other shopping places as well. The current study only focuses on sales promotion in the context of impulse buying in the perspective of international and local tourists. However, there are several elements in the outlet malls such product quality and the environment that might influence both groups differently. Therefore, future research could expand the element by including environment and product quality in order to understand the differences in impulse buying behaviour in the perspective of international and local tourists. Overall, this study provides the understanding of comparison between the groups which would help retailers improvise the price strategy and promotion in order to attract both groups to spend more money.

\section{References}

Abrahams, B. (1997). "It's all in the mind", Marketing, 31-3.

Akram U., Khan M. K., Hui P., Tanveer Y., Akram Z. (2018). Development of E-commerce: Factors influencing online impulse shopping in China, Journal of Electronic in Organizations, 16(2), 29-46.

Alvarez, A. B., and Casielles, R. V. (2005). Consumer evaluations of sales promotion: The effect on brand choice, European Journal of Marketing, 39(1), 54-70.

Amos, C., Holmes, G. R., Keneson, W. C. (2014). A meta-analysis of consumer impulse buying. Journal of Retailing and Consumer Services, 21(2), 86-97.

Andreti J., Zhafira N. H., Akmal S. S., Kumar S. (2013). The analysis of product, price, place, promotion and service quality on customers' buying decision of convenience store: A survey of young adult in Bekasi, West Java, Indonesia, International Journal of Advances in Management and Economics, 2(6), 77-78.

Babin, B. J., Chebat, J. C., and Michon, R. (2004). Perceived appropriateness and its effect on quality, affect and behavior. Journal of Retailing and Consumer Services, 11(5), 287298.

Badgaiyan, A. J., Verma, A., and Dixit, S. (2016). Impulsive buying tendency: Measuring important relationships with a new perspective and an indigenous scale. IIMB Management Review, 28(4), 186-199. 
Berman B., and Evans J.R. (2004). Retail Management: A Strategic Approach, Pearson Prentice Hall.

Brassington, F. and Pettitt, S. (2000). Sales Promotion. In: Principles of Marketing, 2nd ed., FT Prentice Hall, Harlow.

Buil, I., De Chernatony, L., and Martínez, E. (2013). Examining the role of advertising and sales promotions in brand equity creation, Journal of Business Research, 66(1), 115122.

Chaharsoughi, S. A., Hamdard J. (2011). The Affect Of Sales Promotion On Consumer Interest To Purchase In IKCO Automotive Company. Journal of Knowledge Management, Econonic and Information Technology, 1(4), 1-17.

Cheng, Y. H., Chuang, S. C., Wang, S. M., and Kuo, S. Y. (2013). The Effect of Companion's Gender on Impulsive Purchasing: The Moderating Factor of Cohesiveness and Susceptibility to Interpersonal Influence. Journal of Applied Social Psychology, 43(1), 227-236.

Foroughi, A., Buang N. A., Sherilou M. (2011). Exploring Impulse Buying Behavior Among Iranian Tourist In Malaysia. Journal of Global Business and Economic, 3(1), 187-195

Floh, A., and Madlberger, M. (2013). The role of atmospheric cues in online impulse-buying behavior, Electronic Commerce Research and Applications, 12(6), 425-439.

Habibi, F. (2017). The determinants of inbound tourism to Malaysia: A panel data analysis, Current Issues in Tourism, 20(9), 909-930.

Hadjali, H. R., Salimi M., Nazari M., Ardestani M. S. (2012). Exploring Main Factors Affecting on Impulse Buying Behavior, Journal of American Science, 8(1), 245-25

Husnain M., Rehman B., Syed F., Akhtar M. W. (2019). Personal and In-store factors influencing impulse buying behaviour among generation $\mathrm{Y}$ consumer of small cities, Business Perspectives and Research, 7(1), 92-107.

Jee T. W. and Ernest C. D. R (2013), Cosumers' personal value and sales promotion preferences effect on behavioural intention and purchase satisfaction for consumer product, Asia Pacific Journal of Marketing and Logistics, 25(1), 70-101.

Karbasivar A., and Yarahmadi H. (2011). Evaluating effective factors on consumer impulse buying behaviour, Asian Journal of Business Management Studies, 2(4), 174-181.

Karande K., and Ganesh J. (2000). Who shops at factory outlets and why?: An exploratory study, Journal of Marketing and Practice, 8(4), 29-42.

Kchaou, A. S., and Amara, R. Ben. (2014). The Role of Sales Promotion in inducing Impulse Purchases, International Journal of Management Excellence, 3(1), 362-372.

Kiran V., Majumdar M., Kishore K. (2012). Innovation in In-store promotion: Effects on consumer purchase decision, European Journal of Business and Management, 4(9), $36-45$.

Kollat, D. T., and Willett, R. P. (1969). Is impulse purchasing really a useful concept for marketing decisions? Journal of Marketing, 33(1), 79-83.

Kotler P. (2005). Marketing Management: Analysis, Planning, And Control, Prentice- Hall, Inc, Englewood Cliffs, New Jersey.

Laesser, C., and Dolnicar, S. (2012). Impulse purchasing in tourism - learnings from a study in a matured market. Anatolia, 23(2), 268-286.

Lee, L., and Tsai, C. I. (2014). How Price Promotions Influence Postpurchase Consumption Experience over Time, Journal of Consumer Research, 40(5), 943-959.

Li, Z. F., Deng, S., Moutinho, L. (2014). The Impact of Experience Activities on Tourist Impulse Buying: An Empirical Study in China, Asia Pacific Journal of Tourism Research, 20(2), 191-209. 
Liao S. L., Shen Y. C., Chu C. H. (2009). The effect of sales promotion strategy, product appeal and consumer traits on reminder impulse buying behaviour, International Journal of Consumer Studies, 274-284.

Lo L. Y. S., Lin S. W., Hsu L. Y. (2016). Motivation for online impulse buying: A two-factor theory perspective, International Journal of Information Management, 36, 759-772.

Lo, A., Qu, H. (2015). A theoretical model of the impact of a bundle of determinants on tourists' visiting and shopping intentions: A case of mainland Chinese tourists, Journal of Retailing and Consumer Services, 22, 231-243.

Lucas, M., Koff, E. (2014). The role of impulsivity and of self-perceived attractiveness in impulse buying in women. Personality and Individual Differences, 56(1), 111-115.

Moharana, T. R., and Pattanaik, S. (2016). Retail sales promotion in Indian apparel industry, Journal of Research Innovation and Management Science, 3(1), 2454-6542.

Metilda, R. Kartika, M. (2015). The Impact of Sales Promotion on Hedonic Value and Utilitarian Value on Impulse Buying, Indian Journal of Research, 4 (10), 34-37.

Nagadeepa, C., Selvi, J. T., and Pushpa, A. (2015). Impact of Sales Promotion Techniques on Consumers 'Impulse Buyıng Behaviour towards Apparels at Bangalore, Asian Journal of Sciences and Education , 4, 116-124.

Panda T. R. (2016). Influence of sales promotion on buying decision of pesticide brands in India, International Journal of Multidisciplinary Allied Research Review and Practices, 3(2), 423-433.

Park, E. J., Kim, E. Y., Funches, V. M., Foxx, W. (2012). Apparel product attributes, web browsing, and e-impulse buying on shopping websites, Journal of Business Research, 65(11), 1583-1589.

Peattie, S. (1998), Promotional competitions as a marketing tool in food retailing, British Food Journal, 100 (6), 286-94.

Radzi S. M., Hamid A. H. A., Yasin M. F. M. (2017). Visitors' impulse shopping behaviour at Kuala Lumpur International Airport (KLIA) 2, Journal of Tourism, Hospitality and Culinary Arts, 9(2), 317-332.

Raju, K. V., Kumar, D. P., Raju, S. S. (2015). A Comprehensive Review Of Impulse Purchase Process And Various Factors Affecting It, Journal of Business and Management, 17(12), 81-107.

Reynols K.E., Ganesh J., and Luckett M. (2002). Traditional malls vs. factory outlets: Comparing shopper typologies and implications and for retail strategy, Journal of Business Research, 55, 687-696.

Rook, D.W. (1987). The buying impulse, Journal of Consumer Research, 14,189-199

Rook, D. W., and Gardner, M. P. (1993), In the mood: impulse buying's affective antecedents, Research in Consumer Behavior, 6, 1-28

Saad, M., and Metawie, M. (2015). Store environment, personality factors and impulse buying behavior in Egypt: The Mediating Roles of Shop Enjoyment and Impulse Buying Tendencies. Journal of Business and Management Sciences, 3(2), 69-77.

Santini F.D.O., Ladeira W. J., Sampaio C. H., Falcao C. A. (2015). Perception of value, attractiveness and purchase intention: revisiting sales promotion techniques, Review of Business Management, 17 (56), 1173-1192.

Sharma, A., and Nanda, A. (2012). Impulse buying at airport terminals: A case of Indian consumers, Asia Journal of Management Research, 3(1), 68-82.

Shimp, T.A. (2003), Advertising, Promotion, and Supplemental Aspects of Intergrated Marketing Communications, 6th ed., Thomson South-Western, Bostan, MA

Shuleska A. C. (2012). The impact of situational, demographic, and socioeconomic factors on impulse buying in the republic of Macedonia, Journal of East-West Business, 18 (3), 208-230. 
Sierra J.J., and Hyman M.K. (2011). Outlet malls shoppers' intentions to purchase apparel: A dual process perspective, Journal of Retailing and Consumer Services, 18, 341-347.

Sohn, H. K., and Lee, T. J. (2017). Tourists' impulse buying behavior at duty-free shops: the moderating effects of time pressure and shopping involvement, Journal of Travel and Tourism Marketing, 34(3), 341-356.

Stern, H. (1962). Signficance of Buying Impulse, Journal of Marketing, 26(2), 59-62.

Tendai M., and Crispen C. (2009). In-store shopping environment and impulse buying, African Journal of Marketing Management, 1(4), 102-108.

Tourism Malaysia (2017), Industry performance report January to December 2016.

Tourism Malaysia (2015), Intensive government efforts to promote shopping in Malaysia. Retrieve from http://www.tourism.gov.my/media/view/intensive-government-effortsto-promote-shopping-in-malaysia

United Nation World Tourism Organization Tourism Highlight 2018

Valette-Florence, P., Guizani, H., \& Merunka, D. (2011). The impact of brand personality and sales promotions on brand equity, Journal of Business Research, 64(1), 24-28.

Verplanken, B., and Herabadi, A. (2001). Individual differences in impulse buying tendency: feeling and no thinking, European Journal of Personality, 15(1), 71-83.

Virvilaite, R., Saladiene, V. (2012). Models Investigation of Factors Affecting Consumer Impulsive Purchase Behaviour in Retail Environment, Economics and Management, 17(2), 664-671.

Wakefield, K. L., \& Barnes, J. H. (1996). Retailing hedonic consumption: A model of sales promotion of a leisure service. Journal of Retailing, 72(4), 409-427.

Weng, J. T., and Run, E. C. De. (2013). Consumers' personal values and sales promotion preferences effect on behavioural intention and purchase satisfaction for consumer product, Asia Pacific Journal of Marketing and Logistics, 25(1), 70-101.

World Travel and Tourism Council (2017), Travel and tourism economic impact 2016

Xu Y., and Huang J. S. (2014). Effects of price discounts and bonus packs on online impulse buying, Social Behaviour and Personality, 42(8), 1293-1302.

$\mathrm{Xu}, \mathrm{Y}$. (2007). Impact of Store Environment on Adult Generation Y Consumers' Impulse Buying, Journal of Shopping Center Research, 14(1), 39-56.

Ye L. R., and Zhang H. H. (2014). Sales promotion and purchasing intention: Applying the technology acceptance model in consumer-to-consumer marketplaces, International Journal of Business, Humanities and Technology, 4(3), 1-5. 